\title{
Development and application of poly(acrylamide) membrane ion-selective electrodes for use in dipolar aprotic solutions
}

\author{
Jujie Ren and Toshio Nakamura
}

Received March 8, 2005

\begin{abstract}
In order to trace the changes in the activity of ions in dipolar aprotic solvents, poly(acrylamide) membrane based ion selective electrodes were developed in the author's laboratory. This review covers (1) the development of the electrodes, including the synthesis of host compound modified poly(acrylamide); (2) potentiometric response properties of the electrodes; (3) investigations of the response mechanism by means of spectrophotometric and cyclic voltammetric methods; and (4) applications to determine the solubility products of slightly soluble electrolytes in dipolar aprotic solvents , successive complex formation constants of ions with some dipolar aprotic solvent molecules, and standard molar Gibbs energies of ions transfer.
\end{abstract}

\section{Introduction}

The majority of chemical reactions are carried out in solution and the reactivity of solutes is extraordinarily influenced by solvation. In order to promote the desired reaction, nonaqueous solvents, especially dipolar aprotic solvents have been widely used in place of water in experimental laboratories, industry, and many other domains. A suitable choice of nonaqueous solvents makes substances that are insoluble or unstable in water soluble or stable and promotes reactions that are impossible in water. The solubility products of electrolytes, and the activities and Gibbs energies of ions, etc. in dipolar aprotic solvents are quite different from those in aqueous systems. These differences in the thermodynamic properties of electrolytes are important for both theoretical and practical reasons [1-8].

Polymer membrane ion-selective electrode is a very useful tool for detecting the activity changes of ions in solution due to its good reproducibility, stability, and simplicity. Many of these polymer electrodes have been previously discussed [9-11]. In the past few years, the selectivity and lower detection limits of these ion selective electrodes were dramatically improved [12,13]. The response function and

Faculty of Science, Shinshu University, Asahi, Matsumoto 390-8621, Japan selectivity behavior have been well explained by various novel non-classical response principles and some phase-boundary potential models [14]. But almost all of these electrodes were used in aqueous solution.

In order to study the thermodynamic properties of ions, including the relatively weaker metal-ligand complexing interaction between ion-solvent molecules in nonaqueous solutions, a number of ion selective electrodes based on a non-plasticized poly(acrylamide) (PAA) membrane were developed at our laboratory. This paper discusses the preparations, potentiometric properties, response mechanism, and thermodynamic applications of the electrodes in several dipolar aprotic solvents.

\section{Preparations of the electrodes}

PAA was selected to prepare the membrane ion selective electrode due to its stability in dipolar aprotic solvents such as $\mathrm{N}, \mathrm{N}$-dimethylformamide (DMF), N,N-dimethylacetamide (DMA), acetonitrile (AN), n-methyl-2-pyrrolidinone (NMP), propylene carbonate (PC), and so forth. The carboxyl-modified PAA was used to conjugate with various host compounds (Host), which are able to reversibly react with the interest ions in nonaqueous solutions, to produce host compound modified PAA. The typical host compounds used in our research are shown in Table 1 [15-29]. 
Table 1. Host compounds

\begin{tabular}{|c|c|c|c|}
\hline Compound & Structural formula & Designation & Reference \\
\hline Phthalocyaninates (pc) & & $\begin{array}{l}{[\mathrm{M}(\mathrm{pc})]} \\
\mathrm{M}=\mathrm{Co}(\mathrm{II}) \\
\mathrm{Ga}(\mathrm{III}), \mathrm{Sn}(\mathrm{II}), \\
\text { VO }\end{array}$ & $\begin{array}{l}19,20,22,25 \\
27,26 \\
23\end{array}$ \\
\hline Dibenzo-18-crown-6 & & DB18C6 & 15 \\
\hline Benzo-15-crown-5 & & $\mathrm{B} 15 \mathrm{C} 5$ & 21,34 \\
\hline Benzo-12-crown-4 & & $\mathrm{B} 12 \mathrm{C} 4$ & 24 \\
\hline $\begin{array}{l}\text { 5,6-Benzo-4,7,13,16,21,24- } \\
\text { hexacoca-1,10-diazabicyclo } \\
\text { [8.8.8]hexacoxane }\end{array}$ & & Crypt222B & 28,29 \\
\hline $\begin{array}{l}\text { Tetraethylene glycol } \\
\text { monododecyl ether }\end{array}$ & $\mathrm{H}-\left(\mathrm{OCH}_{2} \mathrm{CH}_{2}\right)_{4}-\mathrm{O}-\mathrm{CH}_{2}\left(\mathrm{CH}_{2}\right)_{10} \mathrm{CH}_{3}$ & POE4 & $16,17,18$ \\
\hline $\begin{array}{l}\text { Hexaethylene glycol } \\
\text { monododecyl ether }\end{array}$ & $\mathrm{H}-\left(\mathrm{OCH}_{2} \mathrm{CH}_{2}\right)_{6}-\mathrm{O}-\mathrm{CH}_{2}\left(\mathrm{CH}_{2}\right)_{10} \mathrm{CH}_{3}$ & POE6 & $16,17,18$ \\
\hline
\end{tabular}

These compounds except for POE4 and POE6, which were covalently bonded with PAA by esterification, were converted to the amines (Host- $\mathrm{NH}_{2}$ ) via the respective nitro derivative (Host-NO $\mathrm{N}_{2}$ and then conjugated at the carboxyl group of carboxyl-modified PAA by reaction in DMF following the procedure adopted by Bauminger and Wilchek[30] to obtain the final products, host compound covalently bound PAA: PAA-COOH + $\mathrm{NH}_{2}$-Host $\rightarrow$ PAA-CO-NH-Host $+\mathrm{H}_{2} \mathrm{O}$. For example,

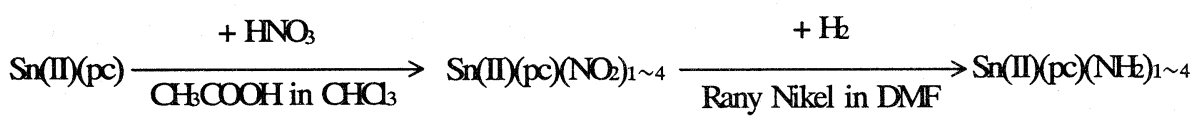

\section{+ PAA(carboxyl modified)}

\section{NN-dicyclohexylcarbodiimide in DMF}

\section{PAACO-NH[Sn(II)(pc)(NH) $0 \sim 3]$ (abbreviated to PAA [Sn(II)(pc)])}

The host compound modified PAA (abbreviated as PAA-Host in the following) was dissolved in water and then spread on the end of a platinum rod with a diameter of $2 \mathrm{~mm}$ housed in a Teflon body. The electrode was stored in silica-gel desiccator and then a thin membrane (thinner than $0.02 \mathrm{~mm}$ ) was formed on the end of it. The electrode was conditioned in cell solution for several hours before use. Two examples of the electrodes in nonaqueous solution are shown schematically in Figs. 1 and 2. 


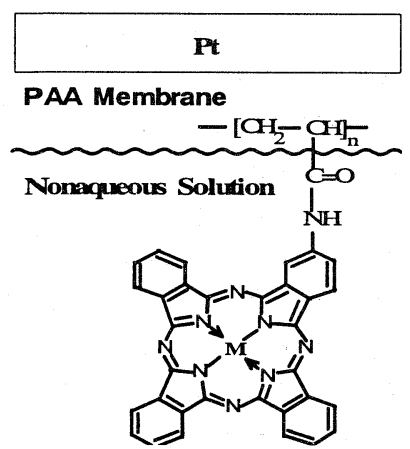

Fig.1 Schematic Diagram of PAA-[M(pc)] Electrode.

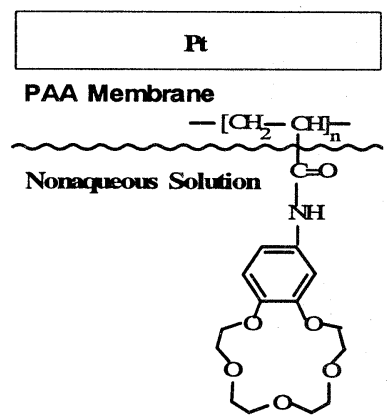

Fig.2 Schematic Diagram of PAA-B15C5 Electrode.

\section{Potential response properties}

The potentiometric responses of the electrodes to various cations and anions were investigated by measuring Cell 1. The emfs were measured with a $\mathrm{pH}$ meter. All compartments of Cell 1 were freshly prepared every time. Steady state potentials were read to $\pm 0.1 \mathrm{mV}$.

$\mathrm{Ag} \mid 10 \mathrm{mM} \mathrm{AgNO}{ }_{3}+10 \mathrm{mM} \mathrm{Et} \mathrm{NClO}_{4}(\mathrm{AN}) \| 50$ $\mathrm{mM} \mathrm{Et} \mathrm{NClO}_{4}$ (D) $\| c \mathrm{R}_{4} \mathrm{NX}$ ( or $\mathrm{MClO}_{4}$ ) $+10 \mathrm{mM}$ $\mathrm{Et}_{4} \mathrm{NClO}_{4}$ (D) | PAA-Host membrane | Pt ......Cell 1

where $\mathrm{D}$ is the solvent; $\mathrm{R}_{4} \mathrm{~N}^{+}$is tetraethylammonium ion $\left(\mathrm{Et}_{4} \mathrm{~N}^{+}\right)$or tetrabutylammonium ion $\left(\mathrm{Bu}_{4} \mathrm{~N}^{+}\right)$, and the counter ion is trifluoromethane sulfonate when $\mathrm{M}$ is $\mathrm{Ca}^{2+} ; \mathrm{X}$ and $\mathrm{M}$ are the interest anion and cation, respectively; $c$ is the concentration of $\mathrm{R}_{4} \mathrm{NX}$ (or $\mathrm{MClO}_{4}$ ), which was added with microburet (e.g. Gilmont S-1200). The change in liquid-junction potentials of Cell 1 during emf measurements was negligible in the experiment [31].

As shown in Table 1, two kinds of host compounds were used in our research. One was the metal phthalocyaninates and the other was the poly(oxyethylene) including cyclic and acyclic polyethers. Electrodes of Pt coated with PAA coupled with metal phthalocyaninates, i.e. PAA- $[\mathrm{M}(\mathrm{pc})]$ electrode (M = Co(II), $\mathrm{Ga}(\mathrm{III}), \mathrm{Sn}(\mathrm{II})$, VO), showed Nernstian or near Nernstian responses to anions such as $\mathrm{F}$ and $\mathrm{CN}^{-}$in $\mathrm{AN}, \mathrm{PC}, \mathrm{DMA}$ and DMF [19-20, 22-23, 25-27]. Electrodes modified with PAA coupled with poly(oxyethylene), i.e. PAA-poly(oxyethylene) (PAA-crown ethers, PAA-acyclic polyethers) electrode, selectively showed Nernstian or near Nernstian responses to cations such as alkali and alkaline-earth metal ions $\left(\mathrm{Li}^{+}, \mathrm{Na}^{+}\right.$, and $\mathrm{K}^{+}, \mathrm{Mg}^{2+}$, $\mathrm{Ca}^{2+}$, and $\left.\mathrm{Ba}^{2+}\right), \mathrm{Cu}^{2+}$, and $\mathrm{Ag}^{+}$. [15-18, 21,24, 28-29].

\section{Response mechanism}

A large number of studies concerning the potential response mechanism of membrane ion selective electrodes, e.g. PVC membrane ion selective electrodes, in aqueous solutions have been conducted [14]. But, there have been very few investigations into the response mechanisms of the membrane electrodes in nonaqueous solutions.

\subsection{PAA-[M(pc)] electrode}

Spectrophotometric and cyclic voltammetric investigations into the interactions of $[\mathrm{M}(\mathrm{pc})]$ with ions in AN, DMA, and NMP were conducted to explain the special selective potential response of the electrodes. In our work, PAA-[Ga(pc)] modified platinum electrode, for example, showed a Nernstian or a near-Nernstian response to $\mathrm{CN}^{-}$and $\mathrm{F}$ in $\mathrm{AN}, \mathrm{PC}$, DMA, and NMP, but it showed a quite poor response to $\mathrm{Cl}^{-}$and $\mathrm{Br}^{-}$in all the above solvents [27]. To understand the peculiar selective response mechanism of the electrode, UV-vis spectrophotometric investigations in AN were carried out. The solution of $\mathrm{Bu}_{4} \mathrm{NF} \cdot 3 \mathrm{H}_{2} \mathrm{O}, \mathrm{Et}_{4} \mathrm{NCN}$, or $\mathrm{Bu}_{4} \mathrm{NBr}$ in $\mathrm{AN}$ was added stepwise to $[\mathrm{Ga}(\mathrm{pc})] \mathrm{Cl}$ saturated $\mathrm{AN}$ solution. Typical spectra are shown in Figs. 3 and 4.

The original $[\mathrm{Ga}(\mathrm{pc})] \mathrm{Cl}$ saturated AN solution had a small absorption peak at $678 \mathrm{~nm}$, however, the peak almost disappeared and new peaks at about $660 \mathrm{~nm}$ and $410-450 \mathrm{~nm}$ appeared and became progressively higher on successive additions of $F$. The added compound itself did not exhibit any absorbance in AN. Almost the same behavior was observed on addition of $\mathrm{CN}^{-}$. 


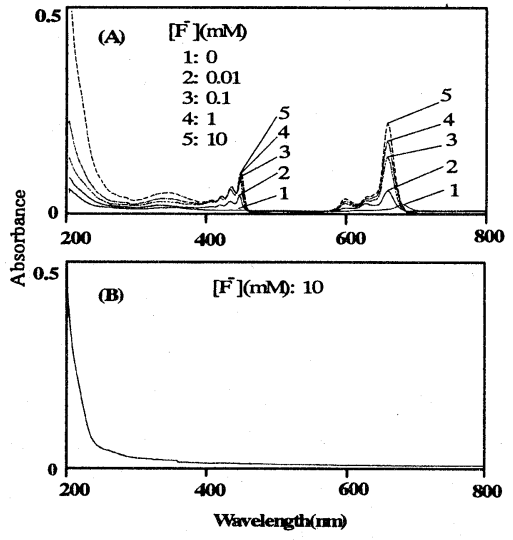

Fig.3. UV-vis spectra of (A) (phthalocyaninato) $\mathrm{Ga}$ (III) $\left([\mathrm{Ga}(\mathrm{pc})]^{+}\right)$saturated acetonitrile (the concentration of $[\mathrm{Ga}(\mathrm{pc})]^{+}$is lower than 0.01 $\mathrm{mM}$ ) containing various concentrations of $\mathrm{F}$ and (B) acetonitrile containing $10 \mathrm{mM}$ of $\mathrm{F}$. Reference was acetonitrile.

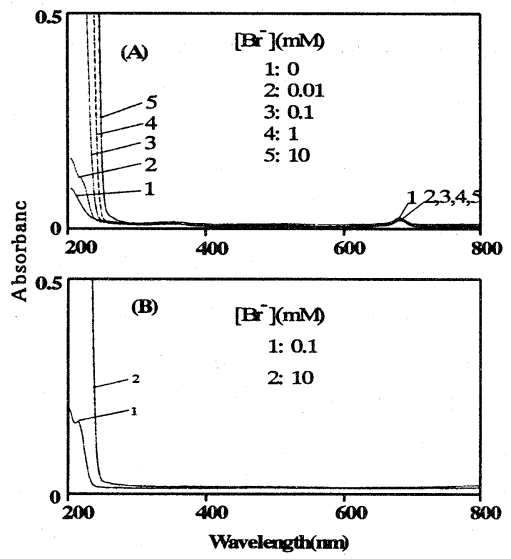

Fig.4. UV-vis spectra of (A) (phthalocyaninato) $\mathrm{Ga}$ (III) ([Ga(III)(pc) $]^{+}$) saturated acetonitrile (the concentration of $[\mathrm{Ga}(\mathrm{pc})]^{+}$is lower than 0.01 $\mathrm{mM}$ ) containing various concentrations of $\mathrm{Br}^{-}$ and (B) acetonitrile containing 0.1 and $10 \mathrm{mM}$ of $\mathrm{Br}$, respectively. Reference was acetonitrile.

On the other hand, as shown in Fig.4, when $\mathrm{Br}^{-}$ was added to $[\mathrm{Ga}(\mathrm{pc})] \mathrm{Cl}$ saturated $\mathrm{AN}$ solution the original absorption peak at $678 \mathrm{~nm}$ showed no change, even when the concentration of $\mathrm{Br}^{-}$became higher. Furthermore, no new peak could be found at $410-450$ $\mathrm{nm}$, although such peaks appeared in the case of $\mathrm{CN}^{-}$ and $\mathrm{F}$. Almost the same behavior was observed in the case of $\mathrm{Cl}^{-}$. These results indicate that $[\mathrm{Ga}(\mathrm{pc})]^{+}$ interacts strongly with $\mathrm{F}$ and $\mathrm{CN}^{-}$but weakly with
$\mathrm{Cl}^{-}$and $\mathrm{Br}^{-}$.

The cyclic voltammetric experiments to study the interaction of $[\mathrm{Ga}(\mathrm{pc})] \mathrm{Cl}$ with $\mathrm{F}$ and $\mathrm{Br}^{-}$in DMA were also carried out. The results are shown in Fig.5. In this figure, the peak-to-peak separations indicate that reversible electron transfer was taking place [32]. The half-wave potentials of this redox couple for $[\mathrm{Ga}(\mathrm{pc})]^{+}$ in DMA was $-920 \mathrm{mV}$ (vs. $\mathrm{Ag}^{+} / \mathrm{Ag}$, for which the potential is $75 \mathrm{mV}$ less than $\mathrm{Fc}^{+} / \mathrm{Fc}$ ). The redox peaks and half-wave potential showed no change when $\mathrm{Br}^{-}$ was added. However, the half-wave potential changed to $-1.27 \mathrm{~V}$ on addition of $\mathrm{F}$. This indicates that F coordinated more strongly with the oxidized form of $[\mathrm{Ga}(\mathrm{pc})]^{+}$than with the reduced form.

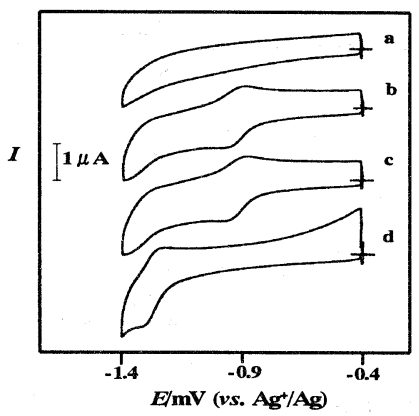

Fig. 5. Cyclic voltammograms recorded at platinum disk electrode in (a) $0.1 \quad \mathrm{M} \mathrm{Et}_{4} \mathrm{NClO}_{4}$ DMA solutions; (b) $[\mathrm{Ga}(\mathrm{pc})] \mathrm{Cl}$ saturated $0.1 \mathrm{M} \mathrm{Et}_{4} \mathrm{NClO}_{4}$ DMA; (c) $[\mathrm{Ga}(\mathrm{pc})] \mathrm{Cl}$ saturated $0.1 \mathrm{M} \mathrm{Et}_{4} \mathrm{NClO}_{4}$ DMA containing $1 \mathrm{mM} \mathrm{Et}{ }_{4} \mathrm{NBr}$; (d) $[\mathrm{Ga}(\mathrm{pc})] \mathrm{Cl}$ saturated $0.1 \mathrm{M} \mathrm{Et}_{4} \mathrm{NClO}_{4}$ DMA containing $1 \mathrm{mM}$ $\mathrm{Bu}_{4} \mathrm{NF} \cdot 3 \mathrm{H}_{2} \mathrm{O}$. Scan rate was $0.100 \mathrm{~V} / \mathrm{s}$.

From the hard-soft acid and base (HSAB) model it can be deduced that the interaction between $\mathrm{Ga}^{3+}$ and the anions should be in the order of $\mathrm{F}>\mathrm{Cl}^{-}>\mathrm{Br}^{-}>$ $\mathrm{CN}^{-}$. The above experimental results, with the exception of the data for $\mathrm{CN}^{-}$, are in close agreement with this supposition. The complex formation reaction of $\mathrm{F}$ with $[\mathrm{Ga}(\mathrm{pc})]^{+}$may also occur because the acidity[33] of AN, whose acceptor number[2] is 18.9, is very weak, making $\mathrm{F}$ in AN extraordinarily active. On the other hand, the ligand field theory, although not very applicable in the case of non-transition metals, gives the complexing ability in the order of $\mathrm{CN}^{-} \gg \mathrm{F}^{-} \gg \mathrm{Cl}^{-}>\mathrm{Br}^{-}$. So, it is reasonable to assume that $\mathrm{Ga}^{3+}$ reacts strongly with $\mathrm{F}$ and $\mathrm{CN}^{-}$, and that, as a result, steady complexing equilibria were established at the sensor membrane-solution interface both 
between $\mathrm{F}$ and $[\mathrm{Ga}(\mathrm{pc}) \mathrm{F}]$, and between $\mathrm{CN}^{-}$and $[\mathrm{Ga}(\mathrm{pc})(\mathrm{CN})]$.

The potentiometric, spectrophotometric, and cyclic voltammetric results reveal that PAA-[Ga(pc)] electrode shows Nernstian or near-Nernstian responses to $\mathrm{F}$ and $\mathrm{CN}^{-}$, due to complexing with the host compounds in sensor membrane, but a non-Nernstian response to the ions, $\mathrm{Cl}^{-}$and $\mathrm{Br}^{-}$, due to weak interaction with the host compound in all of the above solvents. The potentiometric response of the electrode is based on the coordination of the analyte ion as an axial ligand to the center metal of the host compound, $[\mathrm{Ga}(\mathrm{pc})]$, and the defined complexing ability establishes the Nernstian response of the electrode. The three solvents used in this work showed a similar influence on the coordination. Results can also be deduced for PAA-[VO(pc)], PAA-[Co(pc)], and $\mathrm{PAA}-[\mathrm{Sn}(\mathrm{pc})]$ electrodes from spectrophotometric and voltammetric experiments.

4.2 PAA-crown ether and PAA-acyclic polyether electrodes

Cyclic polyethers (crowns) have been synthesized and studied since the 1960's. They can form stable complexes with corresponding cations by ion-dipole interaction between cation and the localized charges (lone pair electrons) of oxygen atoms [34]. The conformation of the molecule is such that it forms a solvation shell around a cation of appropriate charge and atomic radius. A large number of cyclic polyethers have been used as neutral carriers of liquid membrane ion selective electrode, e.g. PVC membrane electrode. But the selective response mechanism of this kind of electrode still remains spectacularly problematic [14,35].

In our research, cyclic polyethers (crowns) were covalently bound with hydrophilic PAA so that they could be used in nonaqueous solution. We have deduced that the electrochemical selectivity and thermodynamic response behaviors of PAA-crown membrane electrode were mainly due to the complex formation of metal ions (alkali metal and alkaline earth cations) with crown at the membrane/solution interface [28]. The potential response mechanism of PAA-acyclic polyether electrode was similar to that of PAA-crown ether electrodes.
We recently confirmed by cyclic voltammetry and chronoamperometry that the PAA membrane possesses porous properties and platinum electrodes modified with PAA membrane yield microelectrode arrays when the membrane is not very thick [36].

\section{Applications of the electrodes}

\subsection{Potentiometric titration in nonaqueous solution}

Because of its accuracy and convenience, potentiometric titration is widely used in studying various types of reactions, e.g. precipitation, complex formation, and redox reactions in nonaqueous solutions. The electrodes developed in our laboratory have successfully been used as indicator electrodes in precipitation reactions.

For example, PAA-B15C5 electrode was used as a $\mathrm{Na}^{+}$indicator electrode in the precipitation titration of $\mathrm{Na}^{+}$with $\mathrm{F}$ in $\mathrm{AN}$ and PC solutions; PAA-[M(pc)] electrodes were used as a $\mathrm{F}$ indicator electrode in the precipitation titration of $\mathrm{F}$ with $\mathrm{Na}^{+}$in $\mathrm{AN}$ solution. Fig. 6 shows the titration and dynamic response curves of $\mathrm{NaClO}_{4}$ with $\mathrm{Bu}_{4} \mathrm{NF}$ in $\mathrm{PC}$ solution by PAA-B15C5 indicator electrode at $25^{\circ} \mathrm{C}$ [37].

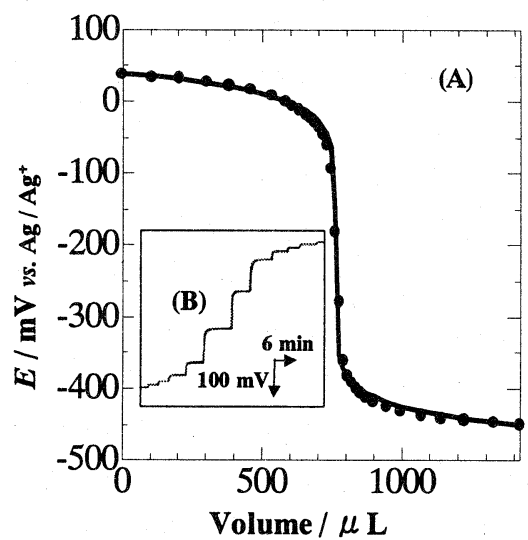

Fig. 6. (A) Titration curve of $10 \mathrm{~mL}$ of $2 \mathrm{mM}$ $\mathrm{NaClO}_{4}$ with $25 \mathrm{mM} \mathrm{Bu} 4 \mathrm{NF} \cdot 3 \mathrm{H}_{2} \mathrm{O}$ in propylene carbonate solution by PAA-B15C5 indicating electrode. $(\bullet)$ and $(-)$ show the measured and calculated values, respectively. (B) Dynamic response curve near the end point. One step on the curve corresponds to one drop of the titrant. 
5.2 Determination of the solubility product constant

When $\mathrm{Na}^{+}$indicator electrode is used in the titration of $\mathrm{Na}^{+}$with $\mathrm{F}$ in PC, for example, Eq. 1 will hold (here, $z=1$ ). The $a_{\mathrm{Na}^{+}}$can be calculated by Eq. 2 while $f_{\mathrm{Na}^{+}}$is calculated by Debye-Huckel equation. The constant $k$ can be calculated from the titration result like that shown in Fig.6. At the equivalent point, $E=E_{\text {ep }}, K_{\text {sp }}$ will be calculated by Eq. 3 .

$$
\begin{aligned}
& E=k+(R T / \mathrm{z} F) \ln a_{\mathrm{Na}^{+}} \\
& a_{\mathrm{Na}^{+}}=f_{\mathrm{Na}^{+}} C_{\mathrm{Na}^{+}} \\
& E_{\mathrm{ep}}=k+(R T / \mathrm{z} F) \ln \left(K_{\mathrm{sp}}\right)^{1 / 2} \\
& E_{\text {after }}=k+(R T / \mathrm{z} F) \ln K_{\mathrm{sp}} / a_{\mathrm{F}^{-}} \\
& a_{\mathrm{F}^{-}}=f_{\mathrm{F}^{-}} c_{\mathrm{F}^{-}}
\end{aligned}
$$

In this method the initial concentration of titrant and titrate must be known (if only one of their concentration is known, the exact concentration of the other can be determined by the titration curve obtained). The validity of Eq. 1 at equivalent point can be checked by calculate the electrode potential after equivalent point, $E_{\text {after, }}$ by Eq. 4 , in which $K_{\text {sp }}$ is obtained by Eq. 3 and $a_{\mathrm{F}}$ is calculated by Eq. 5 . Eq. 3 can be used if calculated curve is consistent with the experimental curve like that shown in Fig. 6.

5.3 Determination of the standard molar Gibbs energy of ion transfer

The dissolution and chemical reactions of a solute are significantly influenced by the solvation and the solvent effect can be predicted quantitatively from the solvation energies of the relevant solutes. The ion solvation energies of electrolyte are important in predicting the behavior of ions and electrolytes in different kinds of solutions.

When the solvation energy of a chemical species $i$ in solvent $\mathrm{R}$ is expressed by $\Delta G_{\mathrm{sv}}^{\mathrm{o}}(\mathrm{i}, \mathrm{R})$ ( this denotes the Gibbs energy change in the process of the dissolution of $i$ in $R$ ) and that in solvent $S$ by $\Delta G_{\text {sv }}{ }^{0}(\mathrm{i}, \mathrm{S})$, the difference between the two is expressed by $\Delta G_{t}^{0}(i, R \rightarrow S)$ and is defined as the Gibbs energy of $i$ transfer from solvent $R$ to $S$ :

$$
\Delta G_{\mathrm{t}}^{\mathrm{o}}(\mathrm{i}, \mathrm{R} \rightarrow \mathrm{S})=\Delta G_{\mathrm{sv}}^{\mathrm{o}}(\mathrm{i}, \mathrm{S})-\Delta G_{\mathrm{sv}}^{\mathrm{o}}(\mathrm{i}, \mathrm{R})
$$

If the species $\mathrm{i}$ is an electrolyte MX and its solubility product in solvent $\mathrm{R}$ is expressed by $K_{\mathrm{sp}}^{\mathrm{R}}$ and that in $\mathrm{S}$ by $K_{\mathrm{sp}}^{\mathrm{S}}$, the value of $\Delta G_{\mathrm{t}}^{\mathrm{o}}(\mathrm{i}, \mathrm{R} \rightarrow \mathrm{S})$ can be obtained from the solubility product of $\mathrm{MX}$ in the two solvents:

$$
\Delta G_{\mathrm{t}}^{\mathrm{o}}(\mathrm{i}, \mathrm{R} \rightarrow \mathrm{S})=R T \ln \left(K_{\mathrm{sp}}^{\mathrm{R}} / K_{\mathrm{sp}}^{\mathrm{S}}\right)
$$

However, when species $\mathrm{i}$ is a single ion, the value of $\Delta G_{\mathrm{t}}^{0}(\mathrm{i}, \mathrm{R} \rightarrow \mathrm{S})$ cannot be determined by purely thermodynamic means. It is necessary to introduce some extra-thermodynamic assumptions. Various extra-thermodynamic assumptions have been proposed. From these assumptions, a number of standard molar Gibbs energies of ions transfer from water to some solvents $\mathrm{S}, \Delta G_{\mathrm{t}}^{\mathrm{o}}(\mathrm{i}, \mathrm{W} \rightarrow \mathrm{S})$, were compiled by $\mathrm{Y}$. Marcus [38]. Here, we propose an indirect method. If $\Delta G_{\mathrm{t}}^{\mathrm{o}}(\mathrm{i}, \mathrm{W} \rightarrow \mathrm{S})$ for one of the ions of electrolyte $\mathrm{MX}, \Delta G_{\mathrm{t}}^{0}(\mathrm{M}, \mathrm{W} \rightarrow \mathrm{S})$ or $\Delta G_{\mathrm{t}}^{0}(\mathrm{X}, \mathrm{W} \rightarrow \mathrm{S})$, is known, the standard molar Gibbs energy of transfer of the counter ion, $\Delta G_{\mathrm{t}}^{0}(\mathrm{X}, \mathrm{W} \rightarrow \mathrm{S})$ or $\Delta G_{\mathrm{t}}^{0}(\mathrm{M}, \mathrm{W} \rightarrow \mathrm{S})$, will be obtained by Eq. 8 when the solubility product constant of MX in two solvents can be determined.

$$
\begin{aligned}
\Delta G_{\mathrm{t}}^{\mathrm{o}} & (\mathrm{MX}, \mathrm{W} \rightarrow \mathrm{S}) \\
& =\Delta G_{\mathrm{t}}^{\mathrm{o}}(\mathrm{X}, \mathrm{W} \rightarrow \mathrm{S})+\Delta G_{\mathrm{t}}^{\mathrm{o}}(\mathrm{M}, \mathrm{W} \rightarrow \mathrm{S}) \\
& =R T \ln \left(K_{\mathrm{sp}}^{\mathrm{W}} / K_{\mathrm{sp}}^{\mathrm{S}}\right)
\end{aligned}
$$

Usually, $K_{\mathrm{sp}}^{\mathrm{w}}$ can be found in the thermodynamic database and solubility product of some electrolyte in solvent $\mathrm{S}, K_{\mathrm{sp}}^{\mathrm{S}}$, can be obtained by our method shown in section 5.2.

5.4 Determination of the successive complex formation constant in nonaqueous solution.

The successive constants $\beta_{\mathrm{i}}$ of the next complex formation reaction of ion $\mathrm{Y}$ in a reference solvent $\mathrm{R}$ with added solvent molecules $\mathrm{D}$ is defined as follows: Overall reaction: $\quad \mathrm{YR}_{\mathrm{m}}+\mathrm{nD}=\mathrm{YD}_{\mathrm{n}}+\mathrm{mR}$

Successive reaction:

$$
\begin{aligned}
& \mathrm{YR}_{\mathrm{m}}+\mathrm{iD}=\mathrm{YR}_{[\mathrm{m}-\mathrm{i}(\mathrm{m} / \mathrm{n})} \mathrm{D}_{\mathrm{i}}+\mathrm{i}(\mathrm{m} / \mathrm{n}) \mathrm{R} \quad(\mathrm{i}=1 \text { to } \mathrm{n}) \\
& \beta_{\mathrm{i}}=\left[a_{\{\mathrm{YR}[\mathrm{m}-\mathrm{i}(\mathrm{m} / \mathrm{n})] \mathrm{Di}\}}\left(\phi_{\mathrm{R}}^{\mathrm{m} / \mathrm{n}}\right)^{\mathrm{i}}\right] /\left[a_{(\mathrm{YRm})}\left(\phi_{\mathrm{D}}\right)^{\mathrm{i}}\right] \\
& =\left[a_{\{\mathrm{YR}[\mathrm{m}-\mathrm{i}(\mathrm{m} / \mathrm{n})] \mathrm{Di}\}} / a_{(\mathrm{YRm})}\right]\left(\phi_{\mathrm{R}}^{\mathrm{m} / \mathrm{n}} / \phi_{\mathrm{D}}\right)^{\mathrm{i}}
\end{aligned}
$$

Where, $\mathrm{YR}_{\mathrm{m}}$ and $\mathrm{YD}_{\mathrm{n}}$ denote $\mathrm{Y}$ solvated by reference solvent $\mathrm{R}$ and that by solvent $\mathrm{D}$ respectively; $a_{(\mathrm{YRm})}$ 
and $a_{\{\mathrm{YR}[\mathrm{m}-\mathrm{i}(\mathrm{m} / \mathrm{n})] \mathrm{Di}\}}$ denote the activities of $\mathrm{YR}_{\mathrm{m}}$ and $\mathrm{YR}_{[\mathrm{m}-\mathrm{i}(\mathrm{m} / \mathrm{n})]} \mathrm{D}_{\mathrm{i}}$, respectively; $\phi_{\mathrm{R}}$ and $\phi_{\mathrm{D}}$ are the volume fractions of $R$ and $D$.

Data concerning relatively weaker ion-solvent molecule interactions in nonaqueous solutions were very scarce at the beginning of our research, especially in the case of magnesium and alkaline earth metal ions. The electrodes developed in our laboratory were successfully used as the indicator electrode to study the step-wise complex formations of ion (Y) with solvent molecules (D) by the cell 2 :

$\mathrm{Ag}\left|10 \mathrm{mM} \mathrm{AgNO}{ }_{3}+10 \mathrm{mM} \mathrm{Et}_{4} \mathrm{NClO}_{4}(\mathrm{AN})\right| \mid 50$ $\mathrm{mM} \mathrm{Et} 4 \mathrm{NClO}_{4}(\mathrm{AN}) \| c \quad \mathrm{Y}\left(\mathrm{ClO}_{4}\right)_{\mathrm{z}}\left(\right.$ or $\left.\left(\mathrm{Et}_{4} \mathrm{~N}\right)_{\mathrm{Z}} \mathrm{Y}\right)+10$ $\mathrm{mM} \mathrm{Et}_{4} \mathrm{NClO}_{4}(\mathrm{R}+\mathrm{D}) \mid$ indicator electrode ...cell 2 where $\mathrm{z}$ is the ionic charge of $\mathrm{Y}$.

In the experiment, a small amount of complex solvent $\mathrm{D}$ is titrated with a micro burette to the solution at a fixed concentration of $\mathrm{Y}$, and the emf is measured after each addition. According to Cox et al [39],

$$
\begin{aligned}
-\triangle G & =\mathrm{z} F \triangle E \\
& =\mathrm{n} R T \ln \phi_{\mathrm{R}}+R T \ln \left[1+\sum \beta_{\mathrm{i}}\left(\phi_{\mathrm{D}} / \phi_{\mathrm{R}}\right)^{\mathrm{i}}\right]
\end{aligned}
$$

where $\triangle E$ is the difference of the electrode potential before and after the addition of D to Cell 1 , and $\mathrm{n}$ is the coordination number. Then, we introduce the two functions $\mathrm{P}$ and $\mathrm{Q}$.

$$
\begin{aligned}
\mathrm{P} & =\phi_{\mathrm{D}} / \phi_{\mathrm{R}} \\
\mathrm{Q} & =\left\{\exp \left[\left(z F \triangle E-\mathrm{n} R T \ln \phi_{\mathrm{R}}\right) / R T\right]-1\right\} / \mathrm{P} \\
& =\beta_{1}+\beta_{2} \mathrm{P}+\beta_{3} \mathrm{P}^{2}+\cdots+\beta_{\mathrm{n}} \mathrm{P}^{(\mathrm{n}-1)}
\end{aligned}
$$

Thus, when $\mathrm{n}$ is known, $\beta_{1}, \beta_{2}, \beta_{3}, \cdots, \beta_{\mathrm{n}}$ can be obtained by multinomial approximate regression using the above equation and Gibbs energy of transfer of $\mathrm{Y}($ or $\mathrm{X})$ is calculated by $\triangle G_{\mathrm{t}}=-R T \ln \beta_{\mathrm{n}}$.

The successive complex formation constants of $\mathrm{Na}^{+}$in reference solvents $\mathrm{AN}$ with added solvents (e.g. DMF, DMSO) have been obtained using the PAA-B15C5 electrode and the values were comparable to those obtained by cation-sensitive glass electrode [40, 41]. For example, the successive constant $\log \beta_{1}$ of the complex formation reaction of $\mathrm{Na}^{+}$in AN with DMF and DMSO was 0.42 and 0.77 using PAA-B15C5 electrode, and 0.38 and 0.76 using cation-sensitive glass electrode (Bechmann Co. Ltd.) at $25^{\circ} \mathrm{C}$. The response ability of the glass electrode had been confirmed by comparison with corresponding metal amalgam electrode [42].

The successive constant $\beta_{1}$ of $\mathrm{Ca}^{2+}$ in reference solvents $\mathrm{AN}$ and $\mathrm{PC}$ with added solvents DMF, NMP, DMA, DMSO, and HMPA has also been obtained by the above method [40,43] as shown in Table 2. This table shows that the complexing ability of $\mathrm{Ca}^{2+}$ with $\mathrm{D}$ increases with the basicity of $\mathrm{D}$ as predicted by Gutmann donor number [2]; the complexing stability of $\mathrm{Ca}^{2+}$ with $\mathrm{D}$ in $\mathrm{PC}$ is relatively weaker than in $\mathrm{AN}$, which has a smaller donor number than PC. These results are reasonable when we consider that the difference in basicity between AN and D is larger than that between PC and D.

Table 2. The successive constant $\beta_{1}$ of the complex formation reaction of $\mathrm{Ca}^{2+}$ in $\mathrm{AN}$ and $\mathrm{PC}$. with some basic solvent molecules at $25^{\circ} \mathrm{C}$

\begin{tabular}{llllll}
\hline Solvents & DMF & NMP & DMA & DMSO & HMPA \\
\hline Donor number & 26.2 & 27.3 & 27.8 & 29.8 & 38.8 \\
$\log \beta_{1}{ }^{a}$ & 1.88 & 2.53 & 2.60 & 2.72 & 3.81 \\
& \pm 0.18 & \pm 0.25 & \pm 0.26 & \pm 0.27 & \pm 0.38 \\
$\log \beta_{1}{ }^{b}$ & 1.47 & 1.56 & 1.60 & 1.86 & 2.78
\end{tabular}

a: the reference solvent was AN (donor number 14.1, [2]).

b: the reference solvent was PC (donor number 15.1, [2]).

\section{Conclusion}

PAA membrane based ion selective electrodes for use in aprotic solution were developed. The host compounds conjugated PAA membrane electrodes can satisfactorily be used to trace activity changes in ions due to the changes in both their concentration and solvation effects. The peculiar selective response mechanism of the electrode developed here was successfully explained by the complex formation reaction at the membrane/nonaqueous solution interface. The electrodes have successfully been applied to the determination of thermodynamic parameters of ions in aprotic solvents. 


\section{References}

1. A. J. Bard Ed., Electroanalytical Chemistry, Volume 8, Marcel Dekker, INC., New York (1975).

2. V. Gutmann Ed., The Donor-Acceptor Approach to Molecular Interactions, Plenum press, New York and London (1978).

3. K. Burger Ed., Solvation, Ionic and Complex formation Reactions in non-Aqueous Solvents, Elsevier Scientific Publishing Company, Amsterdam-Oxford-New York (1983).

4. G. Mamantov and A. I. Popov Ed., Chemistry of Nonaqueous Solutions, VCH Publishers, Inc., New York (1994).

5. K. Izutsu Ed., Electrochemistry in Nonaqueous Solutions, Wiley-VCH, Weinheim (2002).

6. Y. Marcus Ed., Ion Solvation, Wiley \& Sons, New York (1985).

7. Y. Marcus Ed., Ion Properties, Marcel Dekker, New York (1997).

8. Y. Marcus Ed., The Properties of Solvents, Wiley \& Sons, New York (1998).

9. R. L. Solsky, Anal. Chem., 62, 21R-33R (1990).

10. E. Bakker, P. Buhlmann, and E. Pretsch, Electroanalysis, 13, 11(1999).

11. B. Johan, I. Ari, and L. Andrzej, Electroanalysis, 15(5-6), 366(2003).

12. T. Sokalski, A. Ceresa, T. Zwickl, and E. Pretsch, J. Am. Chem. Soc., 119, 11347 (1997).

13. E. Pretsch, Chimia, 55, 875-878 (2001).

14. E. Bakker, P. Buhkmann, and E. Pretsch, Talanta, 62, 834 (2004).

15. T. Nakamura and G.A.Rechnitz, Anal. Chem.,57, 393 (1985).

16. T. Nakamura, K. Ogiwara, K. Izutsu, and G.A. Rechnitz, Bull. Chem. Soc. Jpn., 58, 3409 (1985).

17. T. Nakamura, H. Higughi, and K. Izutsu, Bull. Chem. Soc. Jpn., 62, 3089 (1989).

18. T. Nakamura, M. Komai, S. Hosono, and K. Izutsu, , Anal. Chim. Acta, 238, 351(1990).

19. T. Nakamura, Y. Tsukamoto, and K. Izutsu, BUNSEKI KAGAKU, 39, 689 (1990).

20. T. Nakamura, K. Matsuda, M. Takaguchi, and K.Izutsu, Anal. Sci., 9, 579 (1993).

21. T. Nakamura, C. Hayashi, and K. Izutsu, Anal. Chim. Acta, 292, 305 (1994).

22. T. Nakamura, C. Hayashi, and T. Ogawara, Bull. Chem. Soc. Jpn., 69, 1555 (1996).
23. T. Nakamura, T. Ueda, T. Yanagisawa, and H. Watanabe, Bull. Chem. Soc. Jpn., 72, 235 (1999).

24. T. Nakamura, K. Makino, M. Yanagisawa, and T. Miyasaka, Bull. Chem. Soc. Jpn., 72, 2459 (1999).

25, H. Tatsuta, T. Nakamura, and T. Hinoue, Anal. Sci., 17, 991 (2001).

26. T. Nakamura, J. Ren, T. Hinoue, and K. Umemoto, Anal. Sci., 19, 991 (2003).

27. J. Ren, H. Watanabe, S. Yamamura, and T. Nakamura, Anal. Chim. Acta, 525, 105 (2004).

28. T. Nakamura, Y. Nakamura, T. Kojima, and K. Izutsu, Bull. Chem. Soc. Jpn., 63, 2615 (1990).

29. T. Nakamura, T. Ueda, and K. Fujimori, Bull. Chem. Soc. Jpn., 65, 19 (1992).

30. S. Bauminger and M. Wilcheck, Methods Enzymol, 70, 151 (1980).

31. K. Izutsu, T. Nakamura, M. Muramatsu, and Y. Aoki, J. Electroanal. Chem. 297, 49 (1991).

32. A. J. Bard and L. R. Faulkner Ed., Electrochemical Methods, Fundamentals and Applications (second edition), Wiley, New York (2001).

33. G. D. Christian Ed., Analytical Chemistry (sixth edition), John wiley \&Sons, Inc., USA, 221(2004).

34. C.J Pedersen, J. Am. Chem. Soc., 89, 7017 (1967).

35. M, M. Shultz, O. K. Stefanova, S. B. Mokrov, and K. N. Mikhelson, Anal. Chem., 74(3), 510 (2002).

36. X. Ji, B. Jin, R. Ren, J. Jin, and T. Nakamura, J. Electroanal. Chem., in press.

37. J. Nakashima, J. Ren, J. Jin, and T. Nakamura, The $53^{\text {rd }}$ annual meeting of Japan Society of Analytical Chemistry, Chiba, Sep. 1st-3rd, 270 (2004).

38. Y. Marcus Ed., Ion solvstion, John Wiley \&Sons Limited, New York, 152 (1985).

39. B.G.Cox, A.J. Parker, and W.E. Waghorne, Journal of Physical Chemistry, 78, 1731(1974).

40. T. Nakamura and H. Mongi, Bull. Chem. Soc. Jpn., 70, 2449 (1997).

41. K. Izutsu, T. Nakamura, and K. Iwata, Anal. Chim. Acta, 117, 329 (1980).

42. T. Nakamura, Bull. Chem. Soc. Jpn, 48, 2967 (1975).

43. T. Nakamura, C. Hayashi, and K. Izutsu, Anal. Chim. Acta, 292, 305 (1994). 